\title{
Modeling Services Liberalization: The Case of Tanzania
}

\author{
Jesper Jensen \\ Teca Training \\ Thomas F. Rutherford \\ The Swiss Federal Institute of Technology \\ David G. Tarr \\ The World Bank
}

\begin{abstract}
Despite economic theory and empirical literature that have shown that wide availability of business services contributes significantly to productivity gains and growth, economic modelers have been slow to meaningfully incorporate services into their models. This paper employs a 52-sector, small, open-economy computable general equilibrium model of the Tanzanian economy to assess the impact of the liberalization of regulatory barriers against foreign and domestic business service providers in Tanzania. The model incorporates foreign direct investment in services, and productivity effects in both goods and services markets endogenously through a Dixit-Stiglitz framework. The paper summarizes and builds on the surveys and policy notes of the regulatory regimes in business services in Tanzania, and estimates the ad valorem equivalent of barriers to foreign direct investment. The paper estimates significant gains to Tanzania from services reforms, especially in banking, maritime and road transportation.

\footnotetext{
*Corresponding address: Jesper Jensen, Director of Teca Training, Denmark, Agern Allé 3, Hørsholm 2970 / Thomas F. Rutherford, ETH Zürich, Centre for Energy Policy and Economy, Department of Management, Technology and Economics, Zürichbergstrasse 18, Zürich, Switzerland / Professor of Economics at the Swiss Federal Institute of Technology (ETH-Zürich) / David G. Tarr, The World Bank, MSN MC 3-303 1818 H St., N.W., Washington D.C. 20433, Tel (202) 473-7677, Fax (202) 5221159, E-mail: dtarr@worldbank.org. (C2010-Center for Economic Integration, Sejong Institution, Sejong University, All Rights Reserved.
} 
Decomposition exercises reveal that the largest gains will derive from liberalization of non-discriminatory regulatory barriers.

- JEL Classification: C68; D58; F12; F13; F14

- Keywords: Services Liberalization; General Equilibrium; Endogenous Productivity; Tanzania; Foreign Direct Investment; Imperfect Competition.

\section{Introduction}

Both economic theory and empirical literature have shown that wide availability of business services results in productivity gains to the manufacturing sector and contributes to its international competitiveness. ${ }^{1}$ Despite this, economic modelers have been slow to incorporate services into their models in a way that would allow a meaningful assessment of the impact of services reforms.

In many of the service sectors in Tanzania, the regulatory regime imposes significant burdens on the cost of providing services, both by Tanzanian service providers and by multinationals. Consequently, the number of service providers and their quality is lower than it could be. Reform of the regulatory regimes in Tanzanian services sectors could therefore result in an increase in the number of providers and the quality of business service provision in Tanzania.

Moreover, Tanzania is involved in negotiations of commitments in services in various regional arrangements, such as the European Partnership Agreements, $\mathrm{SADC}^{2}$ and the East African Customs Union. ${ }^{3}$ And in the context of its international negotiations under the Doha Development Agenda, Tanzania may be called upon to make further commitments in the business services area. We shall argue that while there are barriers against foreign investment in business services, in practice, the more significant regulatory barriers in Tanzania are those that raise the costs of providing business services in a non-discriminatory manner. Moreover, Tanzanian commitments at the WTO or in its regional arrangements are

\footnotetext{
${ }^{1}$ We provide a brief review of the literature below. See Jensen et al. (2007) for a more extensive review of the literature.

${ }^{2}$ The South African Development Community (SADC) is a preferential trade area among Botswana, Lesotho, Madagascar, Malawi, Mauritius, Mozambique, Namibia, South Africa, Swaziland, Tanzania, Zambia and Zimbabwe.

${ }^{3}$ The East African Customs Union is a customs union among Tanzania, Uganda, Kenya, Rwanda and Burundi.
} 
considerably less open than its practice. Binding commitments made at the WTO or in regional agreements provide a signal to investors in the services sectors that they are welcome and that the regulatory regime will not be turned against them arbitrarily.

In this paper we develop a 52-sector small open economy comparative static computable general equilibrium model of Tanzania that we believe is appropriate to evaluate the impact of Tanzanian liberalization of services barriers. We adopt the Dixit-Stiglitz-Ethier structure for business services (and for increasing returns to scale goods). The key feature of this framework is "love of variety" which implies endogenous productivity gains from the net introduction of new varieties of service providers or from additional varieties of imperfectly competitive goods. ${ }^{4}$ Key to our model is that we allow foreign direct investment in business services. We estimate that a reduction in the regulatory barriers in services would yield substantial welfare gains in Tanzania, and that the innovations in our model are crucial to the estimates.

We have commissioned surveys and policy notes on the key business services sectors in Tanzania. Based on these surveys and policy notes, we estimate the ad valorem equivalents of the regulatory barriers in business services in Tanzania, both discriminatory against foreign investors as well as non-discriminatory barriers that apply to domestic and multinational service providers. We find that the regulatory costs are higher for foreign firms, but they are very high for domestic firms as well.

This paper is innovative since it numerically assesses liberalization of barriers against both domestic and multinational service providers in a multi-sector applied general equilibrium model where the Dixit-Stiglitz endogenous productivity effects are important to the results. Earlier related work includes the following. Markusen, Rutherford and Tarr (2005) developed a stylized model where foreign direct investment is required for entry of new multinational competitors in services, but they did not apply this model to the data of an actual economy. Brown and Stern (2001) and Dee et al. (2003) employ multi-country numerical models with many of the same features of Markusen, Rutherford and Tarr. Their models contain three sectors, agriculture, manufacturing and services, and are thus also rather stylized.

\footnotetext{
${ }^{4}$ Elasticities of substitution for product categories in the Dixit-Stiglitz framework have been estimated by Broda and Weinstein (2004). They estimate that, although there are variances within the groups, for agriculture, services and goods the Dixit-Stiglitz elasticitiy of substitution is close to three. We choose three as our central Dixit-Stiglitz elasticity of substitution.
} 
The Dixit-Stiglitz endogenous productivity effect from the impact of service sector liberalization on product variety is not mentioned in the results of Brown and Stern and are interpreted as of little relevance in Dee et al..$^{5}$ Konan and Maskus (2006) execute a careful evaluation of the liberalization of barriers against foreign service providers in Tunisia. All sectors in their model are constant returns to scale and perfect competition; barriers in services sectors raise the costs of producing services and allow monopoly rents. They note that their results are likely to be an underestimate of the gains since they do not allow entry of foreign service providers nor endogenous productivity gains from additional varieties of service providers-issues we address in this paper. The papers by Jensen, Rutherford and Tarr (2007) and Rutherford and Tarr (2008) on Russian WTO accession are full economy applications with similar modeling features, but the impact of liberalization of domestic regulatory barriers is not considered in those papers. The paper by Balistreri, Rutherford and Tarr (2009) in Kenya is closest to this model, but tourism is a crucial sector in Tanzania and there are several key issues in the treatment of tourism revenues that are crucial to the results in Tanzania that did not arise in the Kenya model.

The paper is organized as follows. In section II, we summarize the key regulatory issues in the business services sectors, and summarize our procedure for the estimation of the ad valorem equivalents of the regulatory barriers. In section III, we describe the model and the most important data. We describe and interpret the results of our central policy scenarios in section IV. In section V, we examine the impact of different modeling and parameter assumptions on the results. This includes "systematic sensitivity analysis" of the results to the parameters of the model by executing the model 30,000 times.

\section{Overview of the Tanzanian Service Sectors and Estimation of the Ad Valorem Equivalence of the Regulatory Barriers}

In this section, we summarize the key institutional and policy issues in telecommunications, financial services and transportation and explain how we estimated the ad valorem equivalents of regulatory barriers in services. Below we focus on the regulatory problems in ports, insurance and telecommunications. For a

\footnotetext{
${ }^{5}$ There have also been numerical estimates of the benefits of services liberalization where services trade is treated analogously to goods trade, i.e. trade in services is assumed to be entirely cross-border and subject to tariffs. For example, see Brown, Deardorff, Fox and Stern (1996).
} 
discussion of regulatory problems in roads, rail, air transport and banking, see Jensen, Rutherford and Tarr (2008).

\section{A. Transportation}

Tanzania's port, rail and road facilities are serious impediments to trade, as highlighted by the ranking of Tanzania as $137^{\text {th }}$ out of 150 countries on the 2007 Logistics Performance Index. ${ }^{6}$ Although some of the problems are related to infrastructure and require investment, there are serious regulatory barriers and governance problems in regulation that significantly aggravate the problems.

As of early 2008, there were widespread complaints about the container terminal at the port of Dar es Salaam. Tanzanian businessmen complain that congestion in the container terminal of the port is the greatest transport impediment to an increase in exports. The multinational company Tanzania International Container Terminal Services (TICTS) received a concession to operate the container terminal in 2000 , when the throughput was less than 100,000 tons of equivalent units (TEU). As the throughput passed the nominal capacity of 250,000 TEU (it was about 350,000 TEU in 2008), the number of containers loaded or offloaded per hour fell to less than half of what was achieved in 2004 and 2005, at the peak of the port's efficiency. The waiting time for ships to access a berth was 12 days in December 2007, and the average total time for an import container to remain in the terminal ("dwell time") more than doubled from 2004 to 2008 from about 13 days to close to 30 days in 2008. As a consequence, some shipping lines were reducing the frequency of calls to the port, while at least one major shipping line has suspended all services to Dar es Salaam until the crisis is resolved. This congestion is raising costs for both importers and exporters and undermining firms that rely on speed and reliability to market.

Long-term solutions to this problem require investment. There are, however, several regulatory problems that have significantly aggravated the problems. Most importantly, the structure of tariffs for the container terminal operator provides an incentive to keep containers in the port. Container terminal operators typically expect to make most of their revenue from the throughput of containers, and this is what happened in the early years of the concession. However, between 2005 and 2008, more than half of the revenue (and in 2008 more than three quarters) came

\footnotetext{
${ }^{6}$ See http://go.worldbank.org/88X6PU5GV0. http://web.worldbank.org/WBSITE/EXTERNAL/TOPICS/EXTTRANSPORT/EXTTLF/0,,contentMDK: 21514122 menuPK:3875957 page PK:210058 piPK:2100 62 the Site PK:515434,00.html
} 
from storage charges, and this is possible because of the long dwell times.

In addition to the above primarily non-discriminatory cost increasing regulatory barriers, there are discriminatory barriers against foreign firms. A commercial presence in Tanzania is required in order to offer shipping services and foreigners are prohibited from operating in Tanzania, but must operate through a Tanzanian agent. Moreover, formally, although not in practice, the maximum ownership share allowed in a local shipping firm is one percent.

\section{B. Insurance}

Although the structure of the non-life insurance market is competitive (but not the life insurance market), the insurance sector is not well developed. Current regulations impede the growth of the sector. These rules include restricting foreign ownership to two-thirds of capital, requiring insurers to be locally incorporated entities, not allowing foreign branches or wholly owned subsidiaries of foreign insurers, not allowing cooperative and mutual insurance companies and limits that make it less attractive for banks to participate in the distribution of insurance.

There are no foreign reinsurance companies operating in Tanzania. This is partly due to the fact that reinsurance arrangements have, at their core, compulsory reinsurance requirements to TanRe, a company indirectly owned by the government. Moreover, reinsurance companies are prohibited to operate as either branches or as wholly owned subsidiaries of foreign domiciled reinsurers. Reinsuring externally, and insuring for that matter, also requires approval.

\section{Telecommunications}

The government has implemented significant reforms in the sector since the reform program began in 1993. At that time, fixed line telephone services were all that was available and less than $1 \%$ of the population were subscribers. As of September 2008, fixed line subscription had not increased as there were only 123 thousand fixed lines available in Tanzania for a population of almost 38 million. However, the mobile telephone service network has been rapidly expanding, from 127 thousand in 2000, to over 13 million as of end 2008. ${ }^{7}$ These subscribers were receiving service at very competitive prices.

The Tanzanian telecommunications regulatory environment is based on the modern "converged" licensing framework, and is not restrictive regarding entry

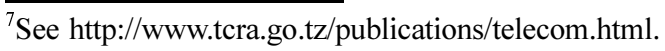


requirements. The non-restrictive regulatory environment has introduced competition in the telecommunications sector, and should be credited with much of the success of the mobile telephone build-out. Nonetheless significant problems remain in the telecommunications sector. Notably: (i) there is a need to develop the Information and Communication Technology (ICT) network efficiently; (ii) internet and data transmission services are very costly. But apart from efficient procurement, this is largely an investment issue beyond regulatory control; and (iii) electronic commerce is seriously constrained by the need to develop credit reference bureaus, the lack of a national payments system, and a legislative framework appropriate for e-business.

\section{Estimation of the Tariff Equivalence of the Regulatory Barriers}

Estimates of the ad valorem equivalents of the regulatory barriers in services are key to the results. In order to make these estimates, we first need to assess the regulatory environment in the services sectors in our model. We commissioned a 54 page survey of the regulatory regimes in key Tanzanian business services sectors, namely, insurance, banking, fixed line and mobile telecommunications services and maritime transportation services. ${ }^{8}$ We supplemented this information based on the policy notes discussed above. These questionnaires and papers provided us with data, descriptions and assessments of the regulatory environment in these sectors.

This methodology involves building on the estimates and methodology of Warren (2000), McGuire and Schulele (2000) and Kang (2000). In different services sectors, these authors evaluated the regulatory environment across many countries. The price of services was then regressed against the regulatory barriers to determine the impact of any of the regulatory barriers on the price of services.

Mircheva (2008) then estimated the ad valorem equivalents of barriers to foreign direct investment in fixed line and mobile telecommunications, banking, insurance and maritime transportation services in Tanzania by assuming that the international regression applies to Tanzania. Mircheva's methodology involves classification of the possible restrictions into separate categories with unique weights summing to one, where the weights are determined based on the international regressions mentioned in the paragraph above. ${ }^{9}$ Mircheva assigned a score to each potential

\footnotetext{
${ }^{8}$ We thank Mr. Cyril Pesha and his law firm associates in Dar es Salaam for leading this research effort. ${ }^{9}$ Mircheva followed the methodology of Kimura, Ando and Fujii (2004) to generate these estimates.
} 
restriction, where the score reflects the level of restriction imposed by the economy. Mircheva estimated two indices: an index of "regulatory barriers" (RB index) where the regulatory barriers impose costs on both domestic and multinational firms in a non-discriminatory manner; and an index of discriminatory barriers against multinational service providers, which we call the foreign discriminatory index (FDR index). ${ }^{10}$

Applying the international regressions and her assessments of the regulatory environment in Tanzania from the questionnaires and other information sources, Mircheva estimated the ad valorem impact of a reduction in barriers ${ }^{11}$ both for

Table 1. Sector Definitions and Initial Ad Valorem Distortions

\begin{tabular}{|c|c|c|c|c|}
\hline & \multirow[b]{2}{*}{ Tariff } & \multirow[b]{2}{*}{ Sales Tax } & \multicolumn{2}{|c|}{ Regulatory barriers } \\
\hline & & & All firms & $\overline{\text { Foreign firms }}$ \\
\hline IRTS Goods and Services & 6.3 & 5.4 & & \\
\hline CRTS Goods and Services & 4.3 & 1.1 & & \\
\hline \multicolumn{5}{|l|}{ Business Services } \\
\hline Telecommunication & & & 3.0 & 8.0 \\
\hline Insurance & & & 18.0 & 36.0 \\
\hline Banking & & & 37.0 & 25.0 \\
\hline Professional business services & & & 10.0 & 15.0 \\
\hline Air transport & & & 20.0 & 2.0 \\
\hline Road transport & & & 30.0 & 5.0 \\
\hline Railway transport & & & 40.0 & \\
\hline Water transport & & & 86.0 & 39.0 \\
\hline Dixit-Stiglitz Goods & 7.4 & 6.8 & & \\
\hline Processed food & 11.1 & 7.1 & & \\
\hline Beverages \& tobacco products & 28.4 & 11.4 & & \\
\hline Textile \& leather products & 29.7 & 14.1 & & \\
\hline Wood paper printing & 11.6 & 3.0 & & \\
\hline Manufacture of basic \& industrial chemicals & 3.6 & 14.2 & & \\
\hline Manufacture of fertilizers \& pesticides & & 0.1 & & \\
\hline Petroleum refineries & 3.2 & 1.5 & & \\
\hline Rubber plastic \& other manufacturing & 6.0 & 7.1 & & \\
\hline Glass \& cement & 7.1 & 18.5 & & \\
\hline Iron steel \& metal products & 5.5 & 2.8 & & \\
\hline Manufacture of equipment & 6.3 & 0.0 & & \\
\hline
\end{tabular}

${ }^{10}$ In order to obtain the estimated score for each restriction, the assigned score is multiplied by the corresponding weight. Finally, the estimated scores for all categories are summed to obtain the restrictiveness indices.

${ }^{11}$ Warren estimated quantity impacts and then using elasticity estimates was able to obtain price impacts. The estimates by Mircheva that we employ are for "discriminatory" barriers against foreign direct investment. 
Table 1. Sector Definitions and Initial Ad Valorem Distortions (Continued)

\begin{tabular}{|c|c|c|}
\hline Agriculture & 15.1 & 1.9 \\
\hline Maize & 0.2 & 0.1 \\
\hline Paddy & 20.5 & \\
\hline Sorghum or millets & 4.6 & 0.0 \\
\hline Wheat & 8.7 & 0.9 \\
\hline Beans & 25.1 & 0.8 \\
\hline Cassava & 25.0 & 5.3 \\
\hline Other cereals & 8.8 & 2.0 \\
\hline Oil seeds & 1.1 & 0.2 \\
\hline Other roots \& tubes & 0.5 & 5.0 \\
\hline Cotton & 1.2 & 2.0 \\
\hline Coffee & 11.8 & 27.8 \\
\hline Tobacco & 11.1 & 2.6 \\
\hline Tea & 18.9 & 28.0 \\
\hline Cashew nuts & 22.2 & 6.2 \\
\hline \multicolumn{3}{|l|}{ Sisal fiber } \\
\hline Sugar & 22.3 & 1.8 \\
\hline Fruits \& vegetables & 6.7 & 0.1 \\
\hline Other crops & 4.3 & 12.4 \\
\hline Poultry \& livestock & 4.4 & 2.8 \\
\hline Other CRTS & 3.9 & 0.9 \\
\hline Fish & 22.7 & 2.5 \\
\hline Hunting \& forestry & & 3.6 \\
\hline Mining \& quarrying & 3.2 & 4.2 \\
\hline Meat \& dairy products & 27.2 & 13.0 \\
\hline Grain milling & 8.6 & 0.4 \\
\hline \multicolumn{3}{|l|}{ Utilities } \\
\hline \multicolumn{3}{|l|}{ Construction } \\
\hline \multicolumn{3}{|l|}{ Wholesale \& retail trade } \\
\hline \multicolumn{3}{|l|}{ Hotels \& restaurants } \\
\hline \multicolumn{3}{|l|}{ Postal communication } \\
\hline \multicolumn{3}{|l|}{ Real estate } \\
\hline \multicolumn{3}{|l|}{ Other services } \\
\hline \multicolumn{3}{|c|}{ Public administration health $\&$ education } \\
\hline Tourism & & \\
\hline
\end{tabular}

discriminatory and non-discriminatory barriers. Mircheva then weighted her fixed line and mobile telecommunications estimates by their market shares to obtain her estimate for communications. The results of the estimates are listed in Table 1. 


\section{Overview of the Model and Key Data}

\section{A. Overview of the Model Formulation}

This paper follows the algebraic structure of the model of Jensen, Rutherford and Tarr (2007) and Rutherford and Tarr (2008). ${ }^{12}$ Here we provide a general description. There are 52 sectors in the model shown in Table 1. These include eight imperfectly competitive business services sectors, eleven imperfectly competitive manufacturing sectors, nineteen competitive agricultural sectors and fourteen competitive manufacturing or services sectors. Primary factors include 8 types of labor grouped both according to gender and to one of four levels of education; child labor; agricultural land; mobile capital; sector-specific capital in imperfectly competitive sectors; and primary inputs imported by multinational service providers, reflecting specialized management expertise or technology of the firm. In each imperfectly competitive sector there is sector specific capital which implies that there are decreasing returns to scale in the use of the mobile factors and supply curves in these sectors slope up. In our central model, we assume that $50 \%$ of the capital in each of the imperfectly competitive sectors is sector specific. We conduct sensitivity analysis with respect to this share by allowing $25 \%$ and $75 \%$ of the capital in each sector to be sector specific.

The are three types of sectors in our model. Regardless of sector, all firms minimize the cost of production.

\section{Competitive goods and services sectors}

In these sectors, production is subject to constant returns to scale and price equals marginal costs with zero profits. This includes all 19 of the agriculture sectors, some food processing sectors such as meat and dairy products and grain milling, and services such as construction, hotels and restaurants, postal communication, real estate, public administration, health and education. In these sectors, products are differentiated by country of origin (what is known as the Armington assumption). All goods producing firms (including imperfectly competitive firms) can sell on the domestic market or export. Firms optimize their output decision between exports and domestic sales based on relative prices and

\footnotetext{
${ }^{12} \mathrm{~A}$ full algebraic description of the model may be found at: http://siteresources.worldbank.org/ INTRANETTRADE/Resources/Topics/Accession/Jensen-Rutherford-Tarr_servicesliberalizationmathappen.pdf.
} 
their constant elasticity of transformation production function.

Tourism is one of the sectors in this category, and given its importance in the Tanzanian economy, it deserves its own discussion. All sales to tourists are considered exports, i.e., the sector does not produce for the domestic market. Based on a Bank of Tanzania (2007a) survey, we have that the inputs of the sector are domestic transportation services, hotel and restaurant services, clothing, gold items, and certain food products, as well as foreign inputs such as international travel expenditures. Given that we have data only on tourist expenditure by sector and on tourism imports and exports, we assume that the output of this sector is produced without value added. But the tourism sector demands domestically produced services and goods that lead to value-added in the Tanzanian economy. Moreover, the sector is intensive in services and this way we capture the impacts on services liberalization on services exports. We discuss the special data issues related to this sector in the data section below.

\section{Goods produced subject to increasing returns to scale ${ }^{13}$}

These goods are differentiated at the firm level. We assume that manufactured goods may be produced domestically or imported. Firms in these industries set prices such that marginal cost (which does not vary with output) equals marginal revenue; and there is free entry, which drives profits to zero. For domestic firms, costs are defined by observed primary factor and intermediate inputs to that sector in the base year data. Foreigners produce the goods abroad at constant marginal cost but incur a fixed cost of operating in Tanzania. The cif import price of foreign goods is simply defined by the import price, and, by the zero profits assumption, in equilibrium the import price must cover fixed and marginal costs of foreign firms. We employ the standard Chamberlinian large group monopolistic competition assumption within a Dixit-Stiglitz framework, which results in constant markups over marginal cost.

For simplicity we assume that the composition of fixed and marginal cost is identical in all firms producing under increasing returns to scale (in both goods and services). This assumption in our Dixit-Stiglitz based Chamberlinian large-group model assures that output per firm for all firm types remains constant, i.e., the model does not produce rationalization gains or losses.

The number of varieties affects the productivity of the use of imperfectly

\footnotetext{
${ }^{13}$ The classification is based on estimates of minimum efficient scale.
} 
competitive goods based on the standard Dixit-Stiglitz formulation. The effective cost function for users of goods produced subject to increasing returns to scale declines in the total number of firms in the industry.

\section{Service sectors characterized by increasing returns to scale and imperfect competition}

These sectors in our model are telecommunications, financial services, transportation services and professional business services. In these services sectors, we observe that some services are provided by foreign service providers on a cross border basis analogous to goods providers from abroad. But a large share of business services are provided by service providers with a domestic presence, both multinational and Tanzanian. ${ }^{14}$ Our model allows for both types of foreign service provision in these sectors. There are cross border services allowed in this sector and they are provided from abroad at constant costs-this is analogous to competitive provision of goods from abroad. Cross border services, however, are not good substitutes for service providers who have a domestic presence. ${ }^{15}$

There are also multinational service firm providers that choose to establish a presence in Tanzania in order to compete with Tanzanian firms directly. When multinationals service providers decide to establish a domestic presence in Tanzania, they will import some of their technology or management expertise. That is, foreign direct investment generally entails importing specialized foreign inputs. ${ }^{16}$ Thus, the cost structure of multinationals differs from national only service providers. Multinationals incur costs related to both imported primary inputs and Tanzanian primary factors, in addition to intermediate factor inputs. Foreign provision of services differs from foreign provision of goods, since the service providers use Tanzanian primary inputs. Domestic service providers do not import the specialized primary factors available to the multinationals. Hence, domestic service firms incur primary factor costs related to Tanzanian labor and capital only. These services are characterized by firm-level product differentiation. For multinational firms, the barriers to foreign direct investment affect their profitability and entry. Reduction in the constraints on foreign direct investment

\footnotetext{
${ }^{14}$ One estimate puts the world-wide cross-border share of trade in services at $41 \%$ and the share of trade in services provided by multinational affiliates at $38 \%$. Travel expenditures $20 \%$ and compensation to employees working abroad 1\% make up the difference. See Brown and Stern (2001, Table 1).

${ }^{15}$ Daniels (1985) found that service providers charge higher prices when the service is provided at a distance.

${ }^{16}$ See Markusen, Rutherford and Tarr et al. (2005) for theoretical development of this type of model.
} 
will induce foreign entry that will typically lead to productivity gains because when more varieties of service providers are available, buyers can obtain varieties that more closely fit their demands and needs (the Dixit-Stiglitz variety effect).

\section{Comparative Steady State Formulation}

In this version of our model, we allow the capital stock to adjust to its steady state equilibrium along with all of the model features we employ in our central scenario, i.e., we allow for tariff and FDI liberalization with endogenous productivity effects as above. The increased availability of services results in an endogenous increase in productivity and an increase in the marginal productivity of capital in particular. An increase in the marginal productivity of capital should increase the accumulation of capital and, in the long run steady state, increase the capital stock. In this scenario the impact on the accumulation of capital from an improvement in the productivity of capital is taken into account. We call this our comparative steady state model.

In the comparative static model, we assume that the capital stock is fixed and the rental rate on capital is endogenously determined. In the comparative steady state model, the logic is reversed. We assume that the capital stock is in its initial steady state equilibrium in the benchmark dataset, but that the capital stock will adjust to a new steady state equilibrium based on a fixed rate of return demanded by investors. That is, if the trade policy shock happens to induce an increase in the rate of return on capital so that it exceeds the initial rate of return, investors will invest and expand the capital stock. Expansion of the capital stock drives down the marginal product of capital, i.e., it drives down the rental rate on capital, until the rate of return on capital falls back to the initial level. ${ }^{17}$ To analyze trade policy, this comparative steady state approach has been employed by many authors, including Harrison, Rutherford and Tarr $(1996,1997)$ and Baldwin et al. (1999) and Francois et al. (1996). The approach ignores the foregone consumption necessary to achieve the higher level of investment and thus, is an upper bound estimate on the long run gains within the framework of the model assumptions.

\section{B. Empirical Basis for Our Modeling Assumptions}

Our model assumes: (1) that discriminatory and non-discriminatory barriers against providers of business services exist in Tanzania; (2) that the removal or

\footnotetext{
${ }^{17}$ The rate of return on investment in our model is the rental rate on capital divided by the cost of a unit of the capital good.
} 
reduction of the barriers will stimulate an increase in FDI and domestic entry in business services; and (3) that additional varieties of business services (and goods in imperfectly competitive sectors) will produce endogenous productivity gains through the Dixit-Stiglitz mechanism. We have discussed the regulatory barriers in business services, and how, in response to a reduction of the barriers, entry has occurred (as in telecommunications and banking) or would be expected to occur (as in maritime services). More systematically, Alessina et al. (2005) find, for a sample of a large number of OECD countries, that regulatory reform, especially liberalization of the barriers against entry, plays a strong role in increasing investment in the sector.

Regarding the productivity impacts in our model, it is the greater availability of varieties that is the engine of productivity growth. Broda and Weinstein (2004) find that increased product variety was responsible for a fall of $1.2 \%$ per year in the "true" U.S. import price index. Hummels and Klenow (2005) and Schott (2004) have shown that product variety and quality are important in explaining trade between nations. Arnold, Mattoo and Javorcik (2007) show that in the Czech Republic, services sector liberalization led to increased productivity of downstream industries, and the key channel through which reform led to increased productivity was allowing foreign entry. Fernandes and Paunov (2008) found a positive and significant effect of foreign direct investment in services on productivity growth in Chile. Fernandes (2007) finds a positive and significant effect of services liberalization in both finance and infrastructure on the productivity of downstream manufacturing in fifteen Eastern European countries.

\section{Data}

The core of the model data is the Social Accounting Matrix (SAM) for 2001 developed by Thurlow and Wobst (2003). The SAM contains 43 sectors, most of which are agricultural and food-producing sectors and only a few are service sectors.

Two sectors in the SAM, "Transport and communication" and "Business and other service activities", account for most business services in Tanzania. Given our focus on services, we disaggregated these sectors into 10 sectors using unpublished national accounts data for the year 2006 from the National Bureau of Statistics of Tanzania.

Data for gross domestic product for the sectors "Transport," "Communications," "Financial intermediation," and "Real estate and business services" is officially 
published (National Bureau of Statistics (2007)). In response to our request, we received a breakdown of these data for the main types of services within each sector. Specifically, the data allows us to disaggregate "Transport and communication" into road transport, railway transport, water transport, air transport, postal services and telecommunication. We disaggregated "business and other service activities" into insurance, banking, business services and other services.

Within each of the two aggregate sectors, the share of gross domestic product by disaggregate sector is used to decompose the corresponding aggregate sector. It is furthermore assumed that the input output structure for all the disaggregate sectors is identical to the input output structure of the corresponding aggregate sector. Along with the addition of the tourism sector, the resulting table has 52 sectors as shown in Table 1.

The SAM contains nine types of labor: Adults are grouped both according to gender and to one of four levels of education. All child labor (age 10 to 14) is the 9th and final category. Capital and agricultural land and a factor called a subsistence factor are the three remaining primary factors of production.

The subsistence factor is a composite of land, labor and capital used in the production for home (own) consumption by households. ${ }^{18}$ The subsistence factor is used in the agricultural and food-producing sectors. In each sector the SAM shows the value of output allocated for home consumption and of output allocated to the market, both of which are coming from the same activity.

\section{Tariff Data}

We were fortunate to receive unusually detailed unpublished collected tariff data at the tariff line level from the Tanzania Revenue Authority. That is, we received data on collected import duties (tariffs) and import values at the eight digit tariff line level. The collected tariff rates for the sectors in our model are obtained by first aggregating the eight digit tariff line level tariff collections and import values to the sectors of our model. The ratio of tariff collections to import values for each sector of our model is then calculated to give estimates of the collected tariff rates, which in turn are incorporated into our SAM. The tariff rates are shown in Table 1. Applying these tariff rates across all sectors implies that tariff revenue in the revised database is about $1.3 \%$ of GDP, which is consistent with collected revenues

\footnotetext{
${ }^{18}$ Data do not allow a breakdown of the subsistence factor into its shares of the other primary factors.
} 
in Tanzania. ${ }^{19}$ The SAM has some detail on taxes, which include direct taxes on households and enterprises, import tariffs, producer taxes, indirect (sales) taxes and factor taxes. The data for import tariffs are replaced with collected tariff rate data for the year 2006 .

\section{Tourism Sector}

The Thurlow and Wobst SAM does not contain the important tourism sector. It allocates international travel expenditure (mainly international tourism) to the "Transport and communication" sector. According to a survey conducted by the Bank of Tanzania (2007a), this is grossly contradicted by the facts. Given our focus on services and the importance of tourism to the Tanzanian economy, we had to correct this problem with the data and add a tourism sector along the lines discussed above. For further details, see Jensen, Rutherford and Tarr (2008).

\section{Share of Market Captured by Multinational Service Providers}

We estimated the market share captured by foreign banks based on asset data for all major banks operating in Tanzania as provided in Appendix II in Bank of Tanzania (2007b). Foreign banks are identified as banks with a foreign ownership share of more than $20 \%$, and the market share is estimated as the share of assets held by foreign banks. Our central values are presented in the table on sensitivity analysis.

\section{Share of Expatriate Labor Employed by Multinational Service Providers}

We obtained estimates of the share of expatriate labor or specialized technology not available to Tanzanian firms that is used by multinational service providers in Tanzania from the survey mentioned above. We found that multinational service providers use mostly local primary factor inputs and only small amounts of expatriate labor or specialized technology. Our estimated share of foreign inputs used by multinationals in Tanzania is presented in the table on sensitivity analysis. $^{20}$

\footnotetext{
${ }^{19}$ For the year 2006, aggregate data from Tanzania show that tariff collections are $1.47 \%$ of GDP.

${ }^{20}$ See Markusen, Rutherford and Tarr (2005) for a detailed explanation on why FDI may be a partial equilibrium substitute for domestic labor but a general equilibrium complement.
} 


\section{Results}

In our "full reform" scenario, we assume that regulatory barriers in business services sectors against both foreign direct investment and domestic investors are cut in half. Given the high dispersion in the tariff (see Table 1), we set tariffs at a uniform tariff level that leaves tariff revenue unchanged. We assume that there is a representative consumer in the economy, and we measure the Hicksian equivalent variation of the consumer. ${ }^{21}$ Except for the "comparative steady state" scenario, all results are based on a comparative static model. The gains come from a combination of effects, so we conduct several scenarios to assess their relative importance.

\section{A. Aggregate Effects}

We estimate that the welfare gains to Tanzania of full reform are equal to $5.3 \%$ of Tanzanian consumption (or $4.8 \%$ of GDP) in the medium term. In the long run, we estimate that the gains could be as high as $16 \%$ of consumption. These medium terms gains derive from three key effects: (1) removal of non-discriminatory inefficient regulatory barriers against service providers; (2) removal of discriminatory regulatory barriers against multinational service providers in Tanzania; and (3) gains from moving to a uniform tariff. We execute several scenarios that allow us to understand the relative impact of these various elements and the mechanisms through which they operate. We discuss three of these below.

The improvement of aggregate welfare is accompanied by a significant increase in factor earnings including the wages of the various types of labor in our model (with the exception of females without a primary school education). ${ }^{22}$ Given the relatively strong expansion of business services (which intensively employs the two more relatively educated males), wages of the two more educated types of male labor increase relatively strongly. Our data indicates that the business services sectors are the most capital intensive sectors in the economy, which explains why the return on capital increases by $5.7 \%$. Land is used only in agriculture and agriculture experiences a slight contraction. Nonetheless, with Dixit-Stiglitz productivity gains, we escape the pessimism of Stolper-Samuelson and we observe

\footnotetext{
${ }^{21}$ See de Melo and Tarr (1992, chapter 3) for an explanation of how to calculate equivalent variation in computable general equilibrium models.

${ }^{22}$ Females without a prime school education are employed more intensively in agriculture, which contracts relative to other sectors.
} 
Table 2. Summary of Macro Estimates

(\%-change from initial equilibrium, unless otherwise indicated)

\begin{tabular}{|c|c|c|c|c|c|c|c|c|}
\hline Scenario definition & $\begin{array}{l}\text { Bench- } \\
\text { mark }\end{array}$ & $\begin{array}{l}\text { Full } \\
\text { Re } \\
\text { form }\end{array}$ & $\begin{array}{c}\text { All } \\
\text { services } \\
\text { barriers }\end{array}$ & $\begin{array}{c}\text { Only } \\
\text { non- } \\
\text { discrimi- } \\
\text { natory } \\
\text { services } \\
\text { barriers }\end{array}$ & $\begin{array}{c}\text { Only } \\
\text { barriers } \\
\text { against } \\
\text { FDI in } \\
\text { services }\end{array}$ & $\begin{array}{c}\text { Only } \\
\text { uniform } \\
\text { tariffs }\end{array}$ & CRTS & $\begin{array}{l}\text { Steady } \\
\text { State }\end{array}$ \\
\hline $\begin{array}{l}\text { Liberalization of regulatory barriers } \\
\text { for all services firms }\end{array}$ & No & Yes & Yes & Yes & No & No & Yes & Yes \\
\hline $\begin{array}{l}\text { Liberalization of discriminatory barri- } \\
\text { ers on foreign services firms }\end{array}$ & No & Yes & Yes & No & Yes & No & Yes & Yes \\
\hline Uniform import tariffs? & No & Yes & No & No & No & Yes & Yes & Yes \\
\hline Steady-state capital stock & No & No & No & No & No & No & No & Yes \\
\hline $\begin{array}{l}\text { Dixit-Stiglitz variety-induced produc- } \\
\text { tivity gains }\end{array}$ & Yes & Yes & Yes & Yes & Yes & Yes & No & Yes \\
\hline \multicolumn{9}{|l|}{ Aggregate welfare } \\
\hline Welfare (EV as $\%$ of consumption) & & 5.3 & 5.0 & 3.7 & 0.8 & 0.2 & 19 & 15.9 \\
\hline Welfare (EV as \% of GDP) & & 4.8 & 4.5 & 3.3 & 0.7 & 0.2 & 1.7 & 14.4 \\
\hline \multicolumn{9}{|l|}{ Government budget } \\
\hline Tariff revenue ( $\%$ of GDP) & 1.3 & 1.2 & 1.3 & 1.3 & 1.3 & 1.3 & 1.2 & 1.0 \\
\hline Tariff revenue & & 0.0 & 11.3 & 9.6 & 1.0 & 0.0 & 0.0 & 0.0 \\
\hline \multicolumn{9}{|l|}{ Aggregate trade } \\
\hline Real exchange rate & & -1.6 & -2.4 & -2.3 & 0.1 & 0.6 & -0.7 & -4.9 \\
\hline Aggregate exports & & 31.4 & 17.3 & 16.3 & -0.3 & 9.5 & 13.0 & 71.4 \\
\hline \multicolumn{9}{|l|}{ Factor Earnings } \\
\hline Subsistence Factor & & 6.5 & 5.8 & 4.4 & 0.9 & 0.4 & 2.3 & 21.7 \\
\hline Child labor (age 10 to 14 ) & & 4.7 & 4.1 & 3.1 & 0.5 & 0.3 & 1.6 & 19.2 \\
\hline Female labor (no formal education) & & 5.6 & 4.3 & 3.3 & 0.4 & 1.0 & 1.9 & 20.0 \\
\hline $\begin{array}{l}\text { Female labor } \\
\text { (not finished primary school) }\end{array}$ & & -2.2 & 2.5 & 1.6 & 0.7 & -4.4 & -3.7 & 6.3 \\
\hline $\begin{array}{l}\text { Female labor } \\
\text { (not finished secondary school) }\end{array}$ & & 5.0 & 4.6 & 3.4 & 0.7 & 0.1 & 1.7 & 18.3 \\
\hline $\begin{array}{l}\text { Female labor } \\
\text { (secondary or higher education) }\end{array}$ & & 3.2 & 3.1 & 1.9 & 1.1 & -0.1 & 1.4 & 12.7 \\
\hline Male labor (no formal education) & & 4.8 & 3.1 & 2.3 & 0.2 & 1.4 & 1.6 & 19.7 \\
\hline $\begin{array}{l}\text { Male labor } \\
\text { (not finished primary school) }\end{array}$ & & 2.4 & 2.6 & 1.7 & 0.4 & -0.4 & -0.1 & 16.8 \\
\hline $\begin{array}{l}\text { Male labor } \\
\text { (not finished secondary school) }\end{array}$ & & 4.4 & 4.0 & 2.7 & 0.9 & 0.3 & 1.7 & 20.6 \\
\hline $\begin{array}{l}\text { Male labor } \\
\text { (secondary or higher education) }\end{array}$ & & 4.3 & 3.9 & 2.6 & 1.2 & 0.2 & 1.9 & 16.2 \\
\hline Capital & & 5.7 & 4.3 & 3.2 & 0.7 & 1.0 & 2.2 & -6.9 \\
\hline Agricultural land & & 3.6 & 2.9 & 2.2 & 0.2 & 0.4 & 0.5 & 17.2 \\
\hline
\end{tabular}


Table 2. Summary of Macro Estimates

(\%-change from initial equilibrium, unless otherwise indicated) (Continued)

\begin{tabular}{lrllllll}
\hline Factor adjustments & & & & & & & \\
$\begin{array}{l}\text { Subsistence Factor } \\
\text { Child labor (age 10 to 14) }\end{array}$ & 1.4 & 1.1 & 0.4 & 0.3 & 0.9 & 0.5 & 1.2 \\
$\begin{array}{l}\text { Female labor } \\
\text { (no formal education) }\end{array}$ & 1.3 & 1.4 & 1.1 & 0.4 & 0.9 & 0.7 & 1.7 \\
$\begin{array}{l}\text { Female labor } \\
\text { (not finished primary school) }\end{array}$ & 5.2 & 2.1 & 1.8 & 0.3 & 3.0 & 3.6 & 7.5 \\
$\begin{array}{l}\text { Female labor } \\
\text { (not finished secondary school) }\end{array}$ & 1.9 & 1.4 & 1.1 & 0.3 & 0.9 & 0.9 & 2.5 \\
$\begin{array}{l}\text { Female labor (secondary or } \\
\text { higher education) }\end{array}$ & 2.4 & 2.1 & 1.5 & 0.5 & 0.7 & 1.1 & 3.6 \\
$\begin{array}{l}\text { Male labor } \\
\text { (no formal education) }\end{array}$ & 1.3 & 1.6 & 1.2 & 0.6 & 1.0 & 0.6 & 1.7 \\
$\begin{array}{l}\text { Male labor (not finished pri- } \\
\text { mary school) }\end{array}$ & 2.8 & 2.0 & 1.5 & 0.5 & 1.7 & 1.7 & 4.0 \\
$\begin{array}{l}\text { Male labor (not finished sec- } \\
\text { ondary school) }\end{array}$ & 2.4 & 2.0 & 1.5 & 0.5 & 1.0 & 1.0 & 4.0 \\
$\begin{array}{l}\text { Male labor (secondary or } \\
\text { higher education) }\end{array}$ & 2.7 & 2.4 & 1.8 & 0.6 & 0.5 & 1.2 & 4.8 \\
$\begin{array}{l}\text { Capital } \\
\text { Agricultural land }\end{array}$ & 2.7 & 2.4 & 1.9 & 0.5 & 1.0 & 1.3 & 0.1 \\
Capital stock and investment & 2.0 & 1.7 & 1.4 & 0.5 & 1.2 & 1.3 & 2.4 \\
\hline Source: Auth' estimas. & & & & & & 27.1 \\
\hline
\end{tabular}

Source: Authors' estimates.

an increase in agricultural rents, albeit at a more modest rate than other factors.

The impact on the movement of workers is not strong as for most categories. Except for females without formal education, less than 3\% must change jobs.

\section{Impact of Removing Non-discriminatory Regulatory Barriers against Tanzanian and Multinational Service Providers}

In this scenario, labeled "only non-discriminatory services barriers," we reduce by $50 \%$ the ad valorem equivalent of the non-discriminatory barriers on domestic and multinational service providers in Tanzania, but there is no reduction in the discriminatory tax on multinationals in the services sectors; nor is there any movement toward tariff uniformity. At $3.7 \%$ of the value of Tanzanian consumption, the largest share of the gains derives from the liberalization of nondiscriminatory regulatory barriers. The results are explained by the fact that the estimated non-discriminatory barriers are rather high in the services sectors, 
especially in the banking (37\%), water (86\%), rail (40\%) and road (30\%) transportation sectors. In addition, we assume that there are real resource costs of the barriers which are freed through the liberalization.

The reduction in the regulatory barriers on the provision of services in Tanzania reduces the cost of providing services in Tanzania for both Tanzanian and multinational service providers. This increases profitability for the provision of services in Tanzania, thereby inducing new entry by both domestic and multinational service providers until zero profits are restored. Consequently, there is an increase in new varieties of services. Tanzanian businesses will then have improved access to services in areas like telecommunication, banking, insurance, transportation and other business services. The additional service varieties in the business services sectors should lower the cost of doing business and result in a productivity improvement for users of these goods through the Dixit-Stiglitz-Ethier effect.

\section{Impact of Foreign Direct Investment Liberalization in Business Services}

In this scenario, labeled "only barriers against FDI in services," we reduce by $50 \%$ the ad valorem equivalent of the discriminatory barriers against multinational service providers who may wish to serve the Tanzanian market, but there is no reduction in the non-discriminatory tax equivalent of the regulatory burden on business service; nor is there any movement toward tariff uniformity. Reducing discriminatory barriers against multinational service providers yields a gain of $0.8 \%$ of Tanzanian consumption. The reduction in the discriminatory tax equivalent on multinational service providers increases profitability for multinational provision of services in Tanzania, thereby inducing new entry by multinational service providers until zero profits are restored. Although there is a loss of domestic service varieties due to increased competition from multinational service providers, there is a net increase in varieties. Tanzanian businesses will then have improved access to services.

\section{Impact of Tariff Uniformity}

In this scenario, labeled only tariffs, we impose tariff uniformity, but we do not change the ad valorem tax equivalent of regulatory barriers on domestic or multinational service providers. In moving to tariff uniformity, the average level of the Tanzanian tariff is unchanged. The level of the tariff is imposed that results in the same average collected tariff rate in Tanzania-the difference in the highs and 
lows are eliminated and replaced with a unique tariff for all sectors. Moving to uniform tariffs yields and estimated welfare gain of $0.2 \%$ of consumption. Our result of gains from tariff uniformity is consistent with the results of Martinez de Pereira (2000) in 13 countries and Harrison, Rutherford and Tarr (1993) for Turkey. These authors have found that moving to tariff uniformity leads to welfare benefits. These results show that, in practice, tariffs do not differ from uniformity due to inverse elasticity-Ramsey optimal tax considerations. The reason for the welfare gains is that the distortion costs of a tariff increase with the square on the tariff. Then moving to uniformity can be expected to benefit the country since it is the very high tariffs that cause the most of distortion costs.

\section{Most Important Sectors}

We have simulated removal of $50 \%$ of the ad valorem equivalents of the nondiscriminatory barriers in individual sectors. The results are that three of the four sectors with the high estimated ad valorem equivalents of the regulatory barriers dominate the comparative static gains. In terms of EV as a percent of consumption, the results are $1.8 \%$ for maritime transportation, $1.3 \%$ for road transport and $1.0 \%$ for banking. ${ }^{23}$

\section{Comparative Steady State Formulation}

The increased availability of services results in an increase in the productivity of capital, which (as discussed above) should increase the accumulation of capital and, in the long-run steady state, increase the capital stock. In this scenario, we allow the capital stock to adjust to its long-run equilibrium.

Then the gains to the Tanzanian economy increase to $15.9 \%$ of consumption or $14.4 \%$ of GDP per year. In this formulation, the incentive to accumulate more capital due to an increase in the marginal productivity of capital is taken into account, but the costs of foregone consumption to achieve the higher capitals stock are not taken into account. So in the context of this model, the estimates should be considered upper bound estimates. On the other hand, Rutherford and Tarr (2002) have shown that in a fully dynamic model with endogenous productivity effects, the gains can be even larger than those estimated here.

\footnotetext{
${ }^{23}$ The fourth sectors, rail transportation, is a much smaller sector and therefore reduction of the regulatory barriers has a lesser welfare impact.
} 
Table 3. Impact on sector activity (\% change from initial equilibrium)

\begin{tabular}{|c|c|c|c|c|c|c|c|}
\hline & $\begin{array}{c}\text { Full } \\
\text { Reform }\end{array}$ & $\begin{array}{c}\text { All } \\
\text { services } \\
\text { barriers }\end{array}$ & $\begin{array}{c}\text { Only } \\
\text { non- } \\
\text { discrimi- } \\
\text { natory } \\
\text { services } \\
\text { barriers }\end{array}$ & $\begin{array}{c}\text { Only } \\
\text { barriers } \\
\text { against } \\
\text { FDI } \\
\text { in ser- } \\
\text { vices }\end{array}$ & $\begin{array}{l}\text { Only uni- } \\
\text { form tar- } \\
\quad \text { iffs }\end{array}$ & CRTS & $\begin{array}{l}\text { Steady } \\
\text { State }\end{array}$ \\
\hline IRTS Goods and Services & 11.4 & 12.8 & 8.3 & 3.1 & -1.1 & 5.8 & 30.1 \\
\hline CRTS Goods and Services & 7.0 & 5.0 & 4.5 & 0.2 & 1.2 & 2.8 & 20.8 \\
\hline Business Services & 37.5 & 36.2 & 24.4 & 8.4 & 0.8 & 16.1 & 67.4 \\
\hline Telecommunication & 21.7 & 22.2 & 13.4 & 5.7 & -0.6 & 7.7 & 43.6 \\
\hline Insurance & 51.2 & 52.6 & 27.7 & 17.8 & -1.0 & 20.1 & 79.9 \\
\hline Banking & 59.2 & 60.6 & 38.8 & 15.8 & -1.0 & 27.4 & 88.4 \\
\hline $\begin{array}{l}\text { Professional business } \\
\text { services }\end{array}$ & 39.9 & 41.4 & 22.1 & 11.8 & -1.0 & 13.5 & 67.6 \\
\hline Air transport & 31.6 & 25.8 & 20.9 & 2.7 & 4.2 & 13.8 & 69.7 \\
\hline Road transport & 35.1 & 29.0 & 24.2 & 2.8 & 4.2 & 16.3 & 73.8 \\
\hline Railway transport & 35.0 & 29.0 & 24.5 & 2.5 & 4.2 & 17.1 & 72.6 \\
\hline Water transport & 24.5 & 25.0 & 21.7 & 9.7 & -0.6 & 13.9 & 44.9 \\
\hline Dixit-Stiglitz Goods & -0.9 & 1.9 & 0.8 & 0.6 & -2.0 & 0.9 & 12.6 \\
\hline Processed food & 4.8 & 2.7 & 1.9 & 0.5 & 2.1 & 3.8 & 15.5 \\
\hline $\begin{array}{l}\text { Beverages \& tobacco } \\
\text { products }\end{array}$ & 0.1 & 5.0 & 3.4 & 0.9 & -4.4 & 0.8 & 11.6 \\
\hline Textile \& leather products & -8.9 & 1.6 & 0.7 & 0.5 & -9.3 & -2.3 & -2.2 \\
\hline Wood paper printing & -4.2 & 1.1 & -0.7 & 1.2 & -4.1 & 0.0 & 4.6 \\
\hline $\begin{array}{l}\text { Manufacture of basic } \\
\& \text { industrial chemicals }\end{array}$ & 5.8 & 4.9 & 3.1 & 1.1 & 1.6 & 1.7 & 11.8 \\
\hline $\begin{array}{l}\text { Manufacture of fertilizers } \\
\& \text { pesticides }\end{array}$ & 0.5 & -10.0 & -8.6 & -1.6 & 9.9 & 2.8 & 13.1 \\
\hline Petroleum refineries & 6.5 & 0.4 & -1.5 & 1.1 & 7.9 & 4.4 & 30.2 \\
\hline $\begin{array}{l}\text { Rubber plastic \& other } \\
\text { manufacturing }\end{array}$ & 2.9 & 2.6 & 0.8 & 1.1 & 1.2 & 1.7 & 28.1 \\
\hline Glass \& cement & 0.9 & 1.3 & 0.6 & 0.4 & -0.3 & 0.8 & 20.6 \\
\hline Iron steel \& metal products & 1.3 & -0.2 & -1.1 & 0.5 & 2.5 & 1.4 & 22.6 \\
\hline Manufacture of equipment & -2.0 & -2.0 & -2.9 & 0.6 & 1.2 & 0.2 & 38.3 \\
\hline Agriculture & -1.0 & -0.8 & -0.7 & -0.4 & -0.1 & -1.0 & 6.3 \\
\hline Maize & 1.6 & 1.1 & 0.8 & 0.2 & 0.5 & 1.0 & 4.5 \\
\hline Paddy & -2.4 & 1.3 & 0.9 & 0.3 & -2.9 & -2.5 & 0.7 \\
\hline Sorghum or millets & 2.8 & 2.6 & 2.0 & 0.4 & 0.1 & 1.2 & 8.6 \\
\hline Wheat & -5.7 & -3.3 & -3.2 & 0.0 & -1.4 & -2.9 & -8.7 \\
\hline Beans & 2.2 & 2.1 & 1.6 & 0.3 & 0.1 & 0.9 & 9.0 \\
\hline Cassava & 0.3 & 0.4 & 0.3 & 0.0 & 0.0 & 0.1 & 1.2 \\
\hline Other cereals & 2.3 & 2.7 & 1.9 & 0.4 & -0.3 & 1.1 & 9.9 \\
\hline Oil seeds & 2.0 & 1.5 & 1.1 & 0.3 & 0.5 & 1.1 & 9.2 \\
\hline
\end{tabular}


Table 3. Impact on sector activity ( $\%$ change from initial equilibrium) (Continued)

\begin{tabular}{|c|c|c|c|c|c|c|c|}
\hline Other roots \& tubes & 1.6 & 1.5 & 1.2 & 0.2 & 0.1 & 0.7 & 6.1 \\
\hline Cotton & -4.1 & 1.6 & 1.0 & 0.4 & -6.3 & -0.4 & 11.1 \\
\hline Coffee & -13.1 & -23.8 & -19.5 & -7.0 & 8.3 & -9.3 & 9.6 \\
\hline Tobacco & 12.5 & 10.0 & 6.8 & 1.9 & 0.4 & 7.13 & 8.7 \\
\hline Tea & -2.4 & -4.1 & -3.9 & -0.1 & -0.6 & -1.6 & 20.9 \\
\hline Cashew nuts & -4.5 & -20.0 & -13.7 & -9.2 & 17.4 & -3.2 & 19.0 \\
\hline Sisal fiber & -8.9 & 1.6 & 0.7 & 0.5 & -9.3 & -2.3 & -2.2 \\
\hline Sugar & -14.9 & -3.1 & -3.0 & 0.1 & -10.4 & -11.3 & -15.5 \\
\hline Fruits \& vegetables & 0.8 & 0.6 & 0.5 & 0.1 & 0.2 & 0.4 & 5.3 \\
\hline Other crops & 3.0 & & 1.9 & 0.2 & 0.5 & 1.3 & 10.5 \\
\hline Poultry \& livestock & 1.6 & 1.4 & 1.1 & 0.1 & 0.2 & 0.5 & 8.4 \\
\hline Other CRTS & 4.0 & 3.6 & 2.6 & 0.6 & 0.3 & 1.7 & 14.7 \\
\hline Fish & 0.8 & -0.4 & -0.1 & -0.2 & 0.9 & 0.3 & 8.9 \\
\hline Hunting \& forestry & 1.1 & 1.5 & 1.0 & 0.3 & -0.3 & 0.5 & 4.9 \\
\hline Mining \& quarrying & 0.8 & -2.2 & -2.3 & 0.0 & 3.1 & 1.7 & 31.1 \\
\hline Meat $\&$ dairy products & -0.1 & 1.2 & 0.9 & 0.2 & -1.1 & -0.6 & 3.8 \\
\hline Grain milling & 3.1 & 2.8 & 2.1 & 0.4 & 0.2 & 1.4 & 10.3 \\
\hline Utilities & 3.1 & 5.0 & 3.3 & 1.1 & -1.6 & 1.6 & 20.3 \\
\hline Construction & 1.9 & 2.0 & 1.4 & 0.4 & -0.1 & 0.8 & 23.5 \\
\hline Wholesale \& retail trade & 2.6 & 2.6 & 1.7 & 0.5 & -0.1 & 1.2 & 18.4 \\
\hline Hotels \& restaurants & 18.2 & 13.7 & 12.0 & 1.1 & 2.8 & 7.6 & 44.5 \\
\hline Postal communication & 8.6 & 9.2 & 5.2 & 2.4 & -0.5 & 3.4 & 28.9 \\
\hline Real estate & 6.7 & 6.7 & 4.7 & 1.3 & -0.1 & 2.5 & 16.7 \\
\hline Other services & 6.5 & 7.6 & 1.9 & 3.7 & -0.8 & 2.4 & 29.2 \\
\hline Tourism & 81.5 & 49.7 & 52.0 & -1.6 & 19.9 & 34.6 & 164.6 \\
\hline $\begin{array}{l}\text { Public administration } \\
\text { health \& education }\end{array}$ & 0.9 & 0.7 & 0.2 & 0.2 & 0.2 & 0.3 & 0.1 \\
\hline
\end{tabular}

Source: Authors' estimates.

\section{B. Sector Results}

In Table 3, we present point estimates for the output effects by sector based on the scenario with our central parameter values. In the next section we display confidence intervals for the sector output changes, where we have run the model 30,000 times with different parameter values. See Jensen, Rutherford and Tarr (2008) for results for imports, exports, employment and price changes by sector. 
Various scenarios are presented in the table, but we focus the discussion on the comparative static full reform scenario.

In the full reform scenario, reduction in the cost of business services (both from removal of regulatory barriers and from the Dixit-Stiglitz variety externality) leads to an increase in the demand for business services and their expansion. The expansion is greatest in the banking and insurance sectors, at 59 and $51 \%$, respectively (this includes multinational output in these sectors). This is primarily explained by the fact that these sectors are among the sectors with the highest level of barriers (both non-discriminatory and discriminatory).

The tourism and hotel and restaurant sectors are the sectors that we estimate will expand the greatest (tourism almost doubles in size). The tourism sector is an intensive user of business services, such as transportation and banking services. Regulatory reforms will decrease the price and allow for quality improvements in these business services, which permits the tourism sector to operate more cheaply and offer better quality services.

Given that we assume that total employment and the capital stock is fixed in the medium term, if labor expands in some sectors, it must contract in other sectors. Given the large expansion in several sectors, especially services, we must have declines in others in the medium term. We estimate declines in output in several sectors, especially those that use business services less intensively. Moreover, since we assume uniform tariffs in our full reform scenario, sugarcane, which is the one of the more highly protected sectors, is estimated to decline.

Since the tourism sector is a major exporter, exports increase and the real exchange rate is estimated to appreciate as a result. Other sectors that rely heavily on exports for their earnings, but do not use business services significantly, are estimated to decline. This includes small declines in the cashew and coffee sectors (5 and $13 \%$, respectively).

\section{Sensitivity Results}

We have discussed the impact of steady state versus comparative static modeling assumptions above. We focus now on the impact of constant returns to scale, barriers that generate rents to dometic agents rather than dissipate real resources, and parameter assumptions for our comparative static results. 


\section{A. Constant Returns to Scale Formulation}

In order to assess the importance of the modeling assumption of endogenous productivity effects from additional varieties, we also consider a "constant returns to scale" (CRTS) version of the model. In this version, there are no endogenous productivity effects from additional varieties of imperfectly supplied goods or services. We estimate that the gains fall to $1.9 \%$ of consumption or $1.7 \%$ of GDP. Thus, the estimated gains are less than $40 \%$ of the total gains when we include endogenous productivity effects of additional services varieties. While the gains are considerably smaller without the gains from services varieties, the gains are large by the standards of CRTS trade models. The reason is that we are considering reforms of regulatory barriers against both foreign and domestic service providers and we assume that the regulatory barriers impose real resource costs in the initial equilibrium, i.e., there are large "rectangles" of rent losses in the CRTS model. The value of $50 \%$ of the rents in the benchmark is $1.34 \%$ of GDP.

\section{B. No Rent Dissipation in the Initial Equilibrium}

In this simulation, we estimate the welfare impacts under an assumption that the barriers generate rents captured by Tanzanian agents. In our central scenario, we assume the costs of firms in terms of their capital, labor and intermediates costs are higher due to the requirements of these barriers. This means that there are "rectangles" of real resource costs that the economy loses due to the barriers. Since the value of rents in the benchmark are equal to $2.68 \%$ of GDP, when we simulate our $50 \%$ liberalization of the barriers, the liberalization frees up resources for productive use by the economy, in an amount equal to $1.34 \%$ of GDP. Then welfare increases, in part due to the additional resources available for productive use.

When the initial rents are captured by domestic agents, they are not losses to the economy. Consequently, no additional resources are freed up as a result of reduction of the barriers, and liberalization should yield lower gains compared with our central scenario. In the comparative static case, the overall welfare gains in this scenario are reduced to $3.5 \%$ of GDP as compared to $4.8 \%$ when the barriers are real resource costs. Thus, the overall benefits of reform are smaller by an amount very close to the value of the rectangle of real resource costs (rents).

\section{Impact of Parameter Assumptions: Piecemeal Sensitivity Analysis}

Three parameters stand out in Table 4 as having a strong impact on the results. 
Table 4. Piecemeal sensitivity analysis - welfare effects

\begin{tabular}{|c|c|c|c|c|c|c|}
\hline \multirow[b]{2}{*}{ Parameter $^{\mathrm{a}}$} & \multicolumn{3}{|c|}{ Parameter value } & \multicolumn{3}{|c|}{$\begin{array}{l}\text { Hicksian equivalent variation }^{\mathrm{b}} \text { with } \\
\text { corresponding parameter }\end{array}$} \\
\hline & Lower & Central & Upper & Lower & Central & Upper \\
\hline$\sigma(v a, b s)$ & 0.5 & 1.25 & 2 & 4.0 & 5.3 & 8.5 \\
\hline$\sigma\left(q_{i}, q_{j}\right)$ & 2 & 3 & 4 & 14.5 & 5.3 & 3.8 \\
\hline$\sigma(D, M)$ & 2 & 4 & 6 & 4.6 & 5.3 & 5.9 \\
\hline$\sigma(L, K)$ & 0.7 & 1 & 1.3 & 5.3 & 5.3 & 5.3 \\
\hline$\sigma\left(A_{1}, \ldots A_{n}\right)$ & 0 & 0 & 0.25 & 5.3 & 5.3 & 5.4 \\
\hline$\sigma(D, E)$ & 2 & 4 & 6 & 5.1 & 5.3 & 5.6 \\
\hline$\varepsilon\left(d_{i}\right)$ & 2 & 4 & 6 & 4.9 & 5.3 & 5.6 \\
\hline$\varepsilon\left(f_{i}\right)$ & 2 & 4 & 6 & 3.6 & 5.3 & 6.7 \\
\hline$\theta m(i)$ & \multicolumn{3}{|c|}{ see table below } & 5.3 & 5.3 & 5.3 \\
\hline$\theta f d i(i)$ & \multicolumn{3}{|c|}{ see table below } & 5.1 & 5.3 & 5.6 \\
\hline
\end{tabular}

$\bar{a}$ The piecemeal sensitivity analysis employs central values for all parameters other than the tested parameter and lump sum tax replacement.

${ }^{\mathrm{b}}$ Hicksian equivalent variation as a percent of the value of consumption in the benchmark equilibrium.

\begin{tabular}{|c|c|c|c|c|c|c|c|}
\hline \multicolumn{8}{|l|}{ Key: } \\
\hline Parameter & \multirow{2}{*}{\multicolumn{7}{|c|}{$\begin{array}{l}\text { Definition of the parameter } \\
\text { Elasticity of substitution between value-added and business services }\end{array}$}} \\
\hline$\sigma(v a, b s)$ & & & & & & & \\
\hline$\sigma\left(q_{i}, q_{j}\right)$ & \multirow{2}{*}{\multicolumn{7}{|c|}{$\begin{array}{l}\text { Elasticity of substitution between firm varieties in imperfectly competitive sectors } \\
\text { "Armington" elasticity of substitution between imports and domestic goods in } \\
\text { CRTS sectors }\end{array}$}} \\
\hline$\sigma(D, M)$ & & & & & & & \\
\hline$\sigma(L, K)$ & \multicolumn{7}{|c|}{ Elasticity of substitution between primary factors of production in value added } \\
\hline$\sigma\left(A_{1}, \ldots A_{n}\right)$ & \multicolumn{7}{|c|}{$\begin{array}{l}\text { Elasticity of substitution in intermediate production between composite Arming- } \\
\text { ton aggregate goods }\end{array}$} \\
\hline$\sigma(D, E)$ & \multicolumn{7}{|c|}{ Elasticity of transformation (domestic output versus exports) } \\
\hline$\varepsilon\left(d_{i}\right)$ & \multicolumn{7}{|c|}{ Elasticity of national service firm supply with respect to price of output } \\
\hline$\varepsilon\left(f_{i}\right)$ & \multicolumn{7}{|c|}{ Elasticity of multinational service firm supply with respect to price of output } \\
\hline$\theta m(i)$ & \multicolumn{7}{|c|}{$\begin{array}{l}\text { Share of value added in multinational firms in sector I due to specialized primary } \\
\text { factor imports in the benchmark equilibrium }\end{array}$} \\
\hline Ofdi(i) & \multicolumn{7}{|c|}{$\begin{array}{l}\text { Share of output of service sector I captured by multinationals firms in the bench- } \\
\text { mark equilibrium }\end{array}$} \\
\hline \multirow{2}{*}{\multicolumn{2}{|c|}{ Parameter values for: }} & \multicolumn{3}{|c|}{$\theta f d i(i)$} & \multicolumn{3}{|c|}{$\theta m(i)$} \\
\hline & & Lower & Central & Upper & Lower & Central & Upper \\
\hline \multicolumn{2}{|c|}{ Telecommunication } & 0.85 & 0.9 & 0.95 & 0.025 & 0.05 & 0.1 \\
\hline \multicolumn{2}{|l|}{ Insurance } & 0.2 & 0.3 & 0.4 & 0.025 & 0.05 & 0.1 \\
\hline \multicolumn{2}{|l|}{ Banking } & 0.3 & 0.4 & 0.5 & 0.025 & 0.05 & 0.1 \\
\hline \multicolumn{2}{|c|}{ Professional business services } & 0.2 & 0.3 & 0.4 & 0.025 & 0.05 & 0.1 \\
\hline \multicolumn{2}{|c|}{ Road transport } & 0.1 & 0.2 & 0.3 & 0.025 & 0.05 & 0.1 \\
\hline \multicolumn{2}{|c|}{ Railway transport } & 0.5 & 0.6 & 0.7 & 0.025 & 0.05 & 0.1 \\
\hline \multirow{2}{*}{\multicolumn{2}{|c|}{ Water transport }} & 0.7 & 0.8 & 0.9 & 0.025 & 0.05 & 0.1 \\
\hline Air transport & & 0.3 & 0.4 & 0.5 & 0.025 & 0.05 & 0.1 \\
\hline
\end{tabular}


The strongest impact comes from $\sigma\left(\mathrm{q}_{\mathrm{i}}, \mathrm{q}_{\mathrm{j}}\right)$, the elasticity of substitution between firm varieties in imperfectly competitive sectors. Unlike other elasticities, a lower value of $\sigma\left(q_{i}, q_{j}\right)$ increases the welfare gains. This is because lower values of this elasticity imply that varieties are less close to each other, so additional varieties are worth more. The next strongest impact comes from $\sigma(\mathrm{va}, \mathrm{bs})$, the elasticity of substitution between value-added and business services. The better firms are able to substitute business services for labor and capital, the more the economy will gain from the reforms that reduce the quality adjusted price of business services. Finally, larger values of $\varepsilon\left(\mathrm{f}_{\mathrm{i}}\right)$, the elasticity of multinational service firm supply with respect to the price of output, also significantly increase the gains, since it means that reforms that open opportunities for multinational service firms, will not be so quickly choked by the increased cost of the specific factor required for multinational firm expansion.

\section{Systematic Sensitivity Analysis}

In the systematic sensitivity analysis, we allow all parameters to change simultaneously. A probability distribution for each parameter is chosen. We typically choose uniform probability distributions, with the lower and upper bounds for the values of the parameters taken from the lower and upper values of

Figure 1. Frequency distribution of sample distribution of welfare gains (based on 30,000 simulations)

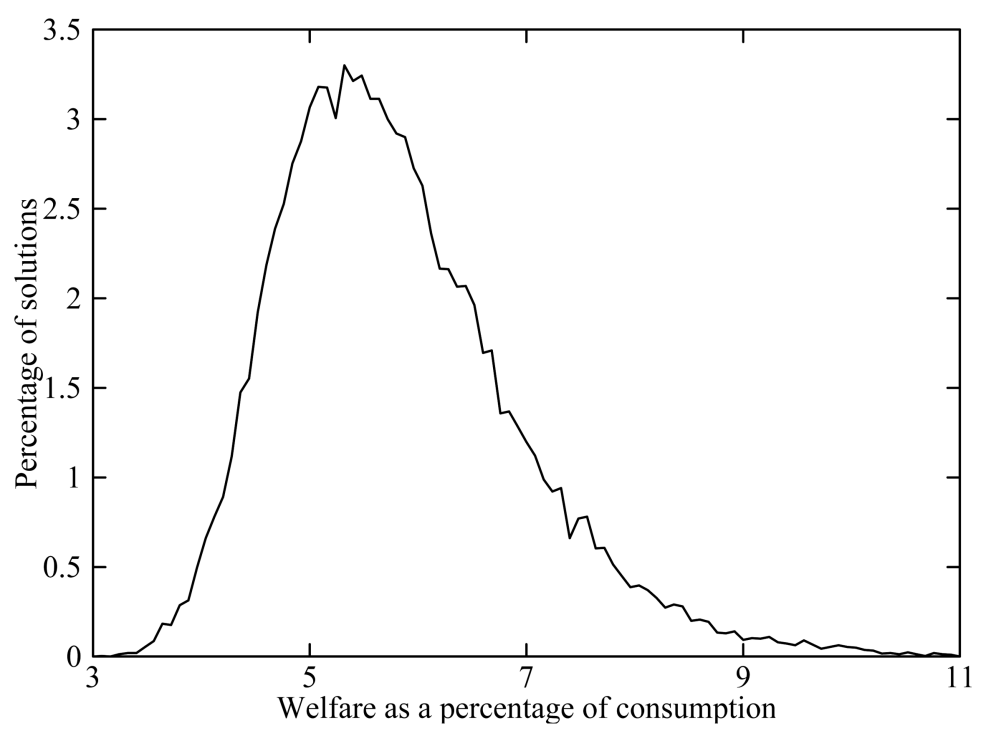


the key parameters presented in Table 4. We furthermore assume that all distributions are stochastically independent. We then run the model 30,000 times. Each time the program chooses a random configuration of parameters and executes the model with this configuration. For each variable in our model, we then harvest

Figure 2. $50 \%$ confidence intervals of percent changes in sector output from the sample distribution (based on 30,000 simulations)

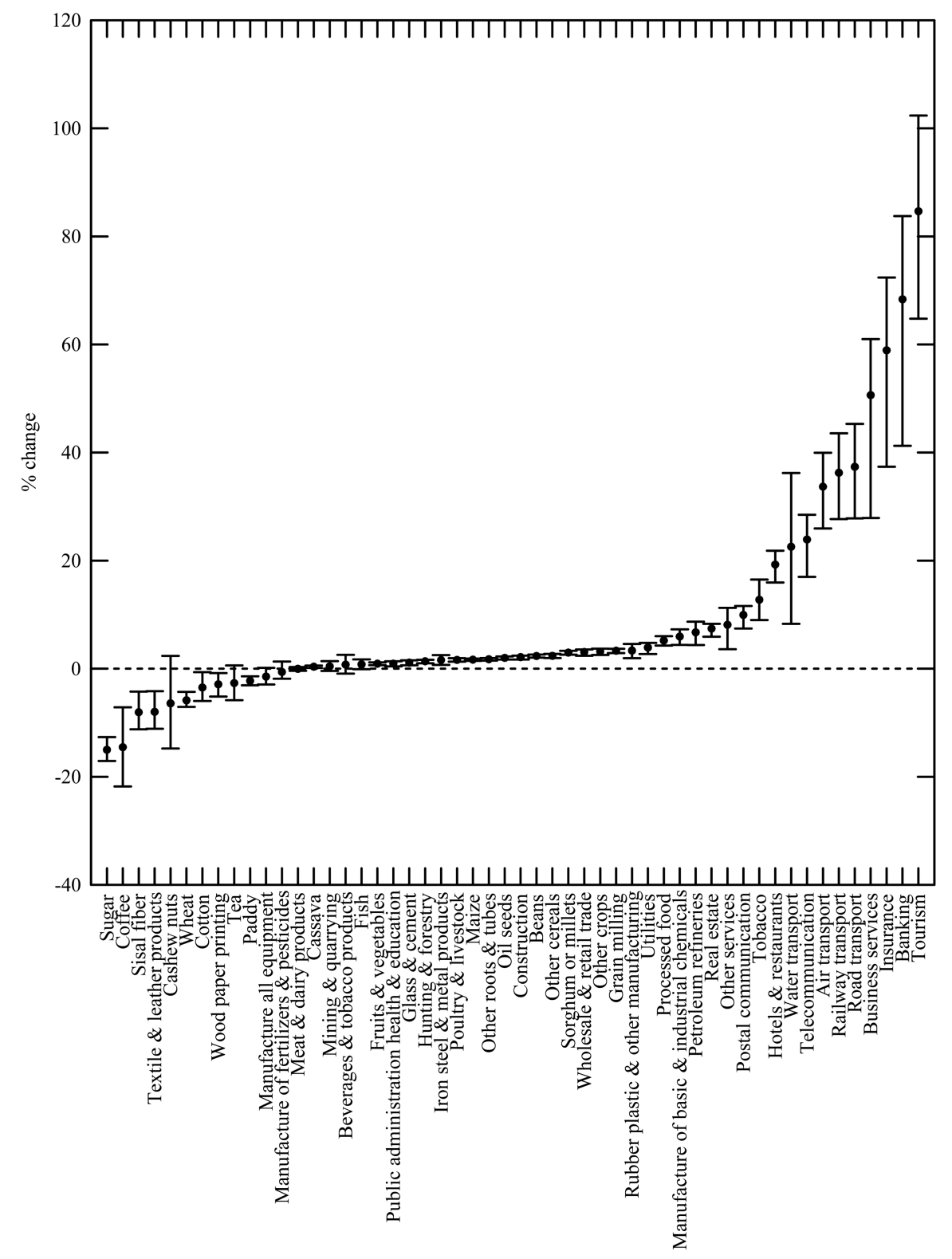


the sample distribution based on the 30,000 solutions. Consequently the sample distribution is not dependent on any particular set of parameter values, but represents results representative of the full distribution of parameter values.

\section{Welfare Results}

Figure 1 shows the frequency distribution of the sample results of the welfare gains as a percent of consumption. The distribution is not symmetric around our central value, since (as Table 4 shows) low values of the Dixit-Stiglitz elasticity generate very large welfare gains. In our 30,000 simulations, the minimum welfare gain was $3.11 \%$, and $99 \%$ of the estimates fall in the range of 3.11 to $9.47 \%$. This shows that the result for substantial welfare gains is robust to parameter specification.

\section{Output Change}

In Figure 2, we display bars that represent fifty percent confidence intervals for aggregate output changes (the point on the bar is our central point estimate). The results suggest robustness for most sectors that we estimate to significantly expand (or contract) with our central elasticities. In particular, we estimate that these sectors will expand (or contract) for virtually all parameter configurations. The figure also shows that the variance in the estimates for the sectors that significantly expand is larger than for other sectors. This is partly explained by the relatively greater use of business services and goods from imperfectly competitive sectors.

\section{Conclusions}

In this paper we have developed an innovative small open economy computable general equilibrium model of the Tanzanian economy that is capable of assessing the impact of the liberalization of regulatory barriers against both domestic and multinational service providers. We find that reduction of the barriers against potential service providers, both foreign and domestic, can yield substantial gains to the Tanzanian economy, and that the innovations in our model are crucial to capturing these impacts.

Received 28 October 2009, Revised 6 October 2010, Accepted 11 October 2010 


\section{References}

Arnold, Jens, Aaditya Matoo and Beata Javorcik (2007), Does Services Liberalization Benefit Manufacturing Firms: Evidence from the Czech Republic, World Bank Policy and Research Working Paper 4109.

Baldwin, Richard and R. Forslid (1999), Putting Growth Effects in CGE Models, R. Baldwin and J.Francois (eds.), Dynamic Issues in Applied Commercial Analysis, The World Bank, Cambridge: Cambridge University Press.

Balistreri, Edward J., Thomas F. Rutherford and David G. Tarr (2009), Modeling Services Liberalization: the case of Kenya, Economic Modelling, 26, pp. 668-679.

Bank of Tanzania (2007a), Tanzania Tourism Sector Survey: The 2005 International Visitors' Exit Survey Report, October.

Bank of Tanzania (2007b), Directorate of Banking Supervision Annual Report for 2006.

Broda, Christian and David Weinstein (2004), Variety, Growth and World Welfare, American Economic Review, 94(2), pp. 139-144.

Brown, Drusilla, Alan Deardorf, Alan Fox and Robert Stern (1996), Liberalization of Services Trade, W. Martin and L. A. Winters, eds., The Uruguay Round and the Developing Countries, Cambridge: Cambridge University Press.

Brown, Drusilla and Robert Stern (2001), Measurement and Modeling of the Economic Effects of Trade and Investment Barriers in Services, Review of International Economics, 9(2), pp. 262-286.

Daniels, P.W. (1985), Service Industries: A Geographical Appraisal, New York: Methuen $\&$ Co.

Dee, Philippa, Kevin Hanslow and Tien Phamduc (2003), Measuring the Costs of Barriers to Trade in Services, Takatoshi Ito and Anne Krueger (eds.), Trade in Services in the Asia-Pacific Region, Chicago: University of Chicago Press.

Dixit, A. and J. Stiglitz (1977), Monopolistic Competition and Optimum Product Diversity, American Economic Review, 76(1), pp. 297-308.

Fernandes, Ana M. and Caroline Paunov (2008), Foreign direct investment in services and manufacturing productivity growth: evidence for Chile, Policy and Research Working Paper 4730, The World Bank.

Fernandes, Ana M. (2007), Structure and performance of the services sector in transition economies, Policy and Research Working Paper 4357, The World Bank.

Francois, Joseph, Bradley McDonald and Hakan Nordstom (1996), Assessing the Uruguay Round, Will Martin and L. Alan Winters (eds.), The Uruguay Round and the Developing Countries, Cambridge: Cambridge University Press.

Hansen, Terje and Tjalling Koopmans (1972), On the Definition and the Computation of a Capital Stock Invariant Under Optimization, Journal of Economic Theory, 5, pp. 487-523.

Harrison, Glenn, Thomas Rutherford and David Tarr (1997), Quantifying the Uruguay Round, Economic Journal, 107(444), pp. 1405-1430, September. 
Harrison, Glenn, Thomas Rutherford and David Tarr (1996), Increased Competition and Completion of the Market in the European Union: Static and Steady State Effects, Journal of Economic Integration, 11(3), pp. 332-365.

Harrison, Glenn, Thomas Rutherford and David Tarr (1993), Trade Reform in the Partially Liberalized Economy of Turkey, The World Bank Economic Review, May.

Hummels, David and Peter Klenow (2005), The Variety and Quality of a Nation's Trade, American Economic Review, 95(3), pp. 704-723.

Jensen, Jesper, Thomas Rutherford and David Tarr (2007), The Impact of Liberalizing Barriers to Foreign Direct Investment in Services: The Case of Russian Accession to the World Trade Organization, Review of Development Economics, 11(3), pp. 482506.

Jensen, Jesper, Thomas Rutherford and David Tarr (2008), Modeling Services Liberalization: The Case of Tanzania, World Bank Policy and Research Working Paper, No. 4801, December. Available at: http://econ.worldbank.org/external/default/main? pagePK $=64165259 \&$ theSitePK $=469372 \&$ piPK $=64165421 \&$ menuPK $=64166093 \&$ ent ityID $=000158349 \_20081228230212$.

Kang, Joog-Soon (2000), Price Impact of Restrictiveness on Maritime Transportation Services", in Findlay, Christopher and Tony Warren (eds), Impediments to Trade in Services: Measurement and Policy Implications, London: Routledge.

Kimura, Fukunari, Mitsuyo Ando and Takamune Fujii (2004), Estimating the Ad Valorem Equivalent of Barriers to Foreign Direct Investment in the Telecommunications Services Sectors in Russia, Available at http://www.worldbank.org/trade/russia-wto.

Konan, Denise Eby and Keith E. Maskus (2006), Quantifying the impact of services liberalization in a developing country, Journal of Development Economics, 81, pp. 142-162.

Markusen, James R, Thomas Rutherford and David Tarr (2005), Trade and Direct Investment in Producer Services and the Domestic Market for Expertise, Canadian Journal of Economics, 38(3), pp. 758-777.

Martinez de Prera, Josefina (2000), Revenue-Neutral Tariff Reform: Welfare Effects of Uniform Tariffs in 13 Developing Countries, Chapter 3 of Ph.D Dissertation, University of Colorado. Available at http://ussub.colorado.edu/ martindp/.

Melo, Jaime de and David G. Tarr (1992), A General Equilibrium Analysis of US Foreign Trade Policy, Cambridge, MA.: MIT Press.

McGuire, Greg and Michael Schuele (2000), Restrictiveness of International Trade in Banking Services, in Findlay, Christopher and Tony Warren (eds), Impediments to Trade in Services: Measurement and Policy Implications, London: Routledge.

Mircheva, Bladislava (2008), Ad valorem equivalence to FDI restrictiveness, Tanzania, Available at: http://sites.google.com/site/davidgtarr/Home/estimates-of-services-barriers.

National Bureau of Statistics of Tanzania, Gross Domestic Product at Current Prices by Selected Economic Activities for the Years 2001-2006, unpublished data.

National Bureau of Statistics of Tanzania (2007), Revised National Accounts Estimates For Tanzania Mainland - Base Year, 2001, Dar es Salaam, July. 
Rutherford, Thomas F. and David Tarr (2008), Poverty Effects of Russian WTO accession: modeling "real" households with endogenous productivity effects, Journal of International Economics, 75(1), pp. 131-150.

Rutherford, Thomas F. and David Tarr (2003), Regional Trading Arrangements for Chile: Do the Results Differ with a Dynamic Model?, Integration and Trade, 7(18), pp. 117139.

Rutherford, Thomas F. and David Tarr (2002), Trade Liberalization and Endogenous Growth in a Small Open Economy, Journal of International Economics, 56(2), March, pp. 247-272

Rutherford, Thomas F. (1999), Applied General Equilibrium Modeling with MPSGE as a GAMS Subsystem: An Overview of the Modeling Framework and Syntax, Computational Economics.

Schott, Peter (2004), Across-Product Versus Within-Product Specialization in International Trade, Quarterly Journal of Economics, 119(2), pp. 647-678.

Tarr, David (2002), On the Design of Tariff Policy: Arguments for and Against Uniform Tariffs, B. Hoekman, A. Mattoo and P. English (eds.), Development, Trade and the WTO: A Handbook, Washington: The World Bank.

Thurlow, James and Peter Wobst (2003), Poverty-Focused Social Accounting Matrices For Tanzania, TMD Discussion Paper No. 112, International Food Policy Research Institute, Washington D.C. USA.

Warren, Tony (2000), The Impact on Output of Impediments to Trade and Investment in Telecommunications Services, Findlay, Christopher and Tony Warren (eds), Impediments to Trade in Services: Measurement and Policy Implications, London: Routledge. 